Short title: Trade-offs in heterogeneous landscapes

\title{
Aligning biodiversity conservation and agricultural production in heterogeneous landscapes
}

\author{
Van Butsic ${ }^{1, *}$, Tobias Kuemmerle ${ }^{2,3}$ \\ Leo Pallud ${ }^{4}$, Kate J. Helmstedt ${ }^{5}$, Leandro Macchi ${ }^{2,6}$, Matthew D. Potts ${ }^{1}$,
}

${ }^{1} 130$ Mulford Hall, Department of Environmental Science Policy and Management, UC Berkeley, Berkeley

CA 94720. vanbutsic@berkeley.edu

${ }^{2}$ Geography Department, Humboldt Universität zu Berlin, Unter den Linden 6, 10099 Berlin, Germany

${ }^{3}$ Integrative Research Institute on Transformations in Human-Environment Systems (IRI THESys), Humboldt Universität zu Berlin, Unter den Linden 6, 10099 Berlin, Germany

${ }^{4}$ ENSTA ParisTech, 828 Bd des Marechaux, 91120 Palaiseau France

${ }^{5}$ School of Mathematical Sciences, Queensland University of Technology, Brisbane, Queensland, 4000, Australia

${ }^{6}$ Instituto de Ecología Regional, UNT - CONICET, Residencia Universitaria Horco Molle, Edificio las Cúpulas, 4107 Tucumán, Argentina

* corresponding author: vanbutsic@berkley.edu, 510-666-5400

This article has been accepted for publication and undergone full peer review but has not been through the copyediting, typesetting, pagination and proofreading process, which may lead to differences between this version and the Version of Record. Please cite this article as doi: $\underline{10.1002 / \text { eap. } 2057}$

This article is protected by copyright. All rights reserved 


\begin{abstract}
Understanding the trade-offs between biodiversity conservation and agricultural production has become a fundamental question in sustainability science. Substantial research has focused on how species' populations respond to agricultural intensification, with the goal to understand whether conservation policies that spatially separate agriculture and conservation or, alternatively, integrate the two are more beneficial. Spatial heterogeneity in both species abundance and agricultural productivity have been largely left out of this discussion, although these patterns are ubiquitous from local to global scales due to varying land capacity. Here, we address the question of how to align agricultural production and biodiversity conservation in heterogeneous landscapes. Using model simulations of species abundance and agricultural yields, we show that trade-offs between agricultural production and species' abundance can be reduced by minimizing the cost (in terms of species abundance) of agricultural production. We find that when species' abundance and agricultural yields vary across landscapes, the optimal strategy to minimize trade-offs is rarely pure land sparing or land sharing. Instead, landscapes that combine elements of both strategies are optimal. Additionally, we show how the reference population of a species is defined has important influences on optimization results. Our findings suggest that in the real world, understanding the impact of heterogeneous land capacity on biodiversity and agricultural production is crucial to designing multi-use landscapes that jointly maximize conservation and agricultural benefits.
\end{abstract}

\title{
Keywords
}

Trade-offs, Land Sparing, Land Sharing, Conservation, Optimization, Spatial heterogeneity.

This article is protected by copyright. All rights reserved 


\section{Introduction}

Growing global demand for agricultural commodities makes protecting biodiversity challenging (Godfray 2011; Tscharntke et al. 2012; Kehoe et al. 2015; Newbold et al. 2015). While there are undoubtedly large opportunities to reduce demand for many agricultural commodities that are detrimental to biodiversity (Chappell \& LaValle 2009; Bajželj et al. 2014; Erb et al. 2016), agricultural production is likely to continue to increase in the future (Tilman et al. 2011), as are conversions from natural lands to agriculture in many parts of the globe (Lambin \& Meyfroidt 2011; Ellis et al. 2013). Trade-offs between species' populations and agricultural production arise in most multi-use landscapes (Fischer et al. 2014). Often, land used for intensive agriculture provides suboptimal habitat for wildlife species, and conversely land reserved for species habitat provides limited agricultural production (Green et al. 2005). Carefully accounting for this trade-off in landscape management and planning is urgently needed.

Managing landscapes requires understanding how species' populations respond to agricultural intensification. A substantial amount of theoretical and empirical work already exists on this relationship (Donald et al. 2006; Kleijn et al. 2009; Newbold et al. 2015; Tsiafouli et al. 2015). This body of literature shows that species respond differently to intensifying land use, with many species declining in abundance, some rapidly even at low levels of intensity, others more gradually, tolerating comparatively high levels of intensity (Phalan et al. 2011; Kremen 2015). Some species even benefit from agriculture, and increase in abundance as long as intensity does not become too high (Wright et al. 2012). Because of this diversity, considering individual species' response to agricultural intensity is a key element for designing landscapes that produce food and agricultural commodities on the one hand and that maintain biodiversity on the other.

Optimal landscapes minimize the trade-offs between biodiversity and agricultural production at the landscape scale. Theoretical work has identified land sparing (i.e., areas of high intensity farming spatially segregated from areas for nature conservation) and land sharing (i.e., wildlifefriendly but lower yielding farming in much of the landscape) landscapes as two archetypical alternatives to such optimal landscapes (Green et al. 2005). Empirical studies have claimed to find support for both, sparing (Phalan et al. 2011; Macchi et al. 2013; Kamp et al. 2015) and sharing (Anand et al. 2010; Clough et al. 2011; Pywell et al. 2012; Mastrangelo \& Laterra 2015) landscapes. 
However, increasingly empirical and theoretical work suggests that optimal landscapes often consist of a mix of both land-use strategies (Butsic \& Kuemmerle 2015; Kremen 2015; Seppelt et al. 2016).

Most of the previous studies carried out in the context of the land-sharing vs. land-sparing debate rely on the assumption of a homogenous landscape, where the same potential yields can be achieved everywhere and where species' abundance varies only according to the intensity of land use. However, agricultural capacity varies in many other ways and is for instance driven by soil quality, slope, rainfall patterns, aridity, minimum temperature, and elevation, even within relatively small geographic extents (Perfecto \& Vandermeer 2010). Species' abundances too, will vary given heterogeneous habitat quality (Wiens 1989). In the real world, landscapes are thus typically heterogeneous in their capacity to produce both agricultural products and species abundance (Grau et al. 2013). Given that such heterogeneity is ubiquitous, the omission of heterogeneity is worrisome and severely limits the applicability of insights derived from land sparing vs. land sharing studies. Understanding the optimal intensity and spatial configuration of land uses in heterogeneous landscapes in order to provide maximum biodiversity value is therefore an area in need of research.

The capacity of a landscape to co-produce agricultural yields and species' abundance may vary independently from one another across landscapes and scales. From a management perspective, the landscapes of greatest conflict are likely to occur where land with the greatest potential for agriculture also has the highest value for biodiversity. This creates management tension: should these highly productive areas be used for agriculture or species conservation?

To shed light on the answer to this question, we used constrained maximization techniques to design landscapes that maximized agricultural output while maintaining target populations of species. We aimed to minimize the marginal costs of agricultural production (in terms of species loss), while taking into account heterogeneous land capacity patterns. We solve the optimization problem for six hypothesized relationships between agricultural and species capacities, with species representing different tolerances to agriculture intensity (i.e., different yield density curves). We solved the model for three different species assemblages: one with only species benefitting from a land sparing landscape (hereafter: sparing species), one with only species benefitting from a land sharing landscape (sharing species), and one with an assemblage of species derived from an empirical study (Kamp et al. 2015). We also used two different reference populations for species of conservation concern: one 
bases the maximization on a reference population that takes place when land-use intensity is equal to zero, as in many empirical examples ( Phalan et al. 2011 \& Kamp et al. 2015), and one that uses the empirical maximum population as the reference population (Butsic \& Kuemmerle 2015). Whereas the first definition assumes management actions should reference natural environments, the second suggest that management should also account for the potential of disturbance-dependent species that might benefit from anthropogenic disturbance, such as land use, dependent on the disturbance intensity (Hanberry 2014; Uchida \& Ushimaru 2014). The results of our optimization provide guidance to land management by offering general insights into under what circumstances high or low productivity land should be used to simultaneously satisfy agriculture and conservation objectives.

\section{Methods}

\section{Model components}

The goal of our analysis was to identify landscapes that maximized agricultural production while maintaining a target population level for a set of species of conservation concern. This is in line with systematic conservation planning (Margules \& Pressey 2000), which is based on quantitative conservation targets (Wilson et al. 2010; Moilanen \& Arponen 2011), and is now practiced widely. Likewise, the use of constrained optimization techniques have proven useful in many other applied and theoretical settings (Metrick \& Weitzman 1998; Kremen et al. 2008).

We used constrained optimization methods with both simulated and empirical data to assess how optimization results are affected by landscape heterogeneity. We modeled a mixed-use landscape, where each parcel of land $k$ is used at some agricultural intensity $y_{k}$, ranging from 0 (no agriculture) to 1 (maximum possible intensity). Maximum agricultural intensity here includes all feasible inputs to production for the location of interest (such as fertilizers or irrigation). For the sake of simplicity, we assume maximum agricultural intensity is equal to one. We defined agricultural capacity $\left(r_{k}\right)$ as the maximum yield a parcel of land $k$ can produce when used at its maximum agricultural intensity. Where $y_{k}$, is the agricultural intensity of parcel $k$. Conceptually, agricultural capacity can be thought of similarly to fertility or yield potential. We defined agricultural production

$X$ on the landscape as a function of agricultural capacity, agricultural intensity, parcel size $a_{k}$, and the 
number of parcels $l$. For simplicity we assume that each parcel on the landscape is the same size, one, and therefore can remove area from our calculations, leaving us with:

$$
X=\sum_{k=1}^{l} r_{k} y_{k}
$$

Beyond yield, the intensity of agriculture also impacts species. We defined species capacity ( $\lambda_{k}$, scaled between 0 and 1) as a parcel's carrying capacity for one species when agricultural intensity was managed optimally for that species. For some species this may be the complete exclusion of agriculture $\left(y_{k}=0\right)$. We used the function $g\left(y_{k}\right)$ to describe the relationship between agricultural intensity on parcel $k$ and species abundance. Species with sharing, sparing, or intermediate responses to agricultural intensity respond differently to agriculture, defined here as one of three potential functional forms for $g\left(y_{k}\right)$ (Figure 1). Here, $g\left(y_{k}\right)$ can be interpreted as the proportion of the maximum carrying capacity that persists on the landscape for a given agricultural intensity.

$$
g\left(y_{k}\right)=\left\{\begin{array}{c}
\left.\lambda_{k}\left(1-y_{k}^{\alpha}\right) \text { for sharing (concave, } \alpha<1\right) \\
\lambda_{k}\left(1-y_{k}^{\alpha}\right) \text { for sparing }(\text { convex, } \alpha>1) \\
\lambda_{k}\left(1-\left(y_{k}^{\alpha}-y_{k}^{\beta}\right)\right) \text { for intermediate, } \beta>0, \alpha>1, \alpha>\beta
\end{array}\right.
$$

If $\alpha$ is less than one, $g\left(y_{k}\right)$ is a concave function, if $\alpha$ is greater than one $g\left(y_{k}\right)$ is a convex function. When $\beta$ is greater than 1, a species has an intermediate relationship (Figure 1). For the species assemblages that are all sharing species or all sparing species, we use simulated values that are comparable to those used in Butsic \& Kuemmerle 2015 (and that are in line with forms that have been found empirically). For the landscape where there are sparing, sharing and intermediate species, we use functional forms that were found in empirical work by Kamp et al. (2015) where they calculate the relationship between species populations and agricultural profit. We did not include species which did not have statistically significant relationships between abundance and land-use intensity or "winner" species, as these are likely not of conservation concern. We note that Kamp et al. focus on steppe birds and different patterns may hold for different taxa or for birds in different biomes.

Because different species have widely different populations, we apply the maximization algorithm to maintain a proportion of the population, instead of the population itself (i.e, $30 \%$ of a reference population, instead of a certain number of individuals). The proportion of the population to be maintained is calculated relative to a reference population, where the reference population can be 
understood as the population a manager uses to make decisions. We used two alternative methods to calculate the reference population for each species. First, the reference population is defined as: $\mathrm{M}_{\mathrm{mp}}=\operatorname{Max} \mathrm{g}\left(\mathrm{y}_{\mathrm{k}}\right), 1 \leq \mathrm{y} \geq 0$,

That is, the reference population $\left(\mathrm{M}_{\mathrm{mp}}\right)$ is the actual maximum of $\mathrm{g}\left(\mathrm{y}_{\mathrm{k}}\right)$ obtained when agricultural intensity is between zero and one. For sharing and sparing species this will take place when land use intensity is equal to zero. For intermediate species, this will take place when agricultural intensity is between zero and one. The proportion of this reference population on a parcel, $\mathrm{n}_{\mathrm{k}}$, is therefore $\mathrm{n}_{\mathrm{k}}=\frac{1}{M_{m p}} \mathrm{~g}\left(\mathrm{y}_{\mathrm{k}}\right)$

This reference population is similar to the one used in Butsic and Kuemmerle 2015, and references the empirical maximum population that can take place on a given parcel in the landscape. We refer to this reference population as the maximum population baseline, as the reference population is the empirical maximum population.

Second, we also solve the optimization problem where the reference population is the population of each species when agricultural intensity equals zero. With this reference population, a manager assumes that the species population when land use intensity is equal to zero is the correct population to base management actions That is:

$$
\mathrm{M}_{\mathrm{nh}}=\mathrm{g}\left(\mathrm{y}_{\mathrm{k}}\right) \text {, where } \mathrm{y}_{\mathrm{k}}=0
$$

For sparing and sharing species $\mathrm{M}_{\mathrm{nh}}=\mathrm{M}_{\mathrm{mp}}$, but this is not the case for intermediate species. In the maximization process, we therefore define the percentage of the maximum population as:

$\mathrm{n}_{\mathrm{k}}=1$ if $\mathrm{g}\left(\mathrm{y}_{\mathrm{k}}\right) \geq \mathrm{M}_{\mathrm{nh}}, \mathrm{n}_{\mathrm{k}}=\frac{1}{M_{n h}} \mathrm{~g}\left(\mathrm{y}_{\mathrm{k}}\right)$ if $\mathrm{g}\left(\mathrm{y}_{\mathrm{k}}\right)<\mathrm{M}_{\mathrm{nh}}$

This reference population is the same as has been used by Phalan et al (2011) and Kamp et al. (2015). In this case, the manager does not value a population over $\mathrm{M}_{\mathrm{nh}}$, and therefore the optimization routine does not attempt to find solutions where the population is greater than $\mathrm{M}_{\mathrm{nh}}$. We refer to this as the natural habitat baseline to indicate that the reference population is the population when there is zero agricultural intensity, i.e., the landscape is untransformed.

We note here that the reference population does not matter for strictly sharing or sparing species, because these species always reach their maximum population when agricultural intensity is equal to zero. However, for intermediate species, the distinction between maximum population or 
natural habitat baselines may be important. Disturbance-dependent species, for example, may have higher populations when there is low land-use intensity compared to when there is no land use (or other disturbances), which is only captured by the maximum population baseline (Figure 1. Panel A gold lines). Using the natural habitat baseline assumes that the relevant baseline for management is when no land use takes place, and therefore population targets for these species are always assumed to be met when land-use intensity is equal to zero (Figure 1. Panel B, gold lines).

\section{Relationships between agricultural capacity and species capacity}

Given these model components, we explored six potential relationships between agricultural capacity and species capacity (Figure 2). First, we considered a landscape where agricultural capacity (the maximum potential yield) per parcel and species capacity (the maximum potential abundance - i.e., carrying capacity - of a species per parcel) were homogenous. Thus, on such a landscape, each parcel had the same value of species capacity and agricultural capacity. Most empirical and theoretical studies on land sharing/sparing have made this assumption (Green et al. 2005; Phalan et al. 2011).

Second, we considered a landscape where agricultural capacity varies, but species' capacity did not. We refer to this case as agricultural heterogeneity. This may be the case if agricultural yields are more sensitive to landscape features than species' abundance.

Third, we assessed the proportional case, where agricultural capacity and species capacity changed proportionally to each other across the landscape. That is, the ratio of agricultural capacity and species capacity was constant across the landscape, even as the actual values differed from parcel to parcel, such that:

$$
\frac{\lambda_{i} j}{r_{i}}=1, \quad \forall(i, j) \in[1, N] \mathrm{x}[1, J]
$$

Where $i$ is the parcel and $j$ is the species. This would be the case if the same factors that increased agricultural capacity - soil quality, rainfall, temperature - also impacted species' carrying capacity in the same way and to the same degree.

Fourth, we evaluated the case where species' capacity and agricultural capacity were negatively related. That is, parcels with high species capacity had lower agriculture capacity and vice versa. We name this case reverse.

This article is protected by copyright. All rights reserved 
Fifth, we described a system where species capacity was higher than agricultural productivity on high capacity land, but lower on low capacity land. That is, areas that are well-suited for farming are also well-suited for species, but on low-capacity land agriculture fares even worse relative to the target species. For this situation, there is a point where the relative capacity changes from $\lambda_{i j}>r_{i}$ to $\lambda_{i j}<r_{i}$. For example, if this change happened at $N_{1}$ we defined a species positive landscape, which took the form of:

$$
\begin{aligned}
& \lambda_{i j}>r_{i} \forall(i, j) \in\left[1, N_{1}\right] \mathrm{x}[1, J] \\
& \lambda_{i j}<r_{i} \forall(i, j) \in\left[N_{1}, N\right] \mathrm{x}[1, J]
\end{aligned}
$$

This would be the situation where at high levels of agricultural capacity, species capacity was relatively higher than agricultural capacity, but for low values of agricultural capacity, the reverse was true. This would be the case in landscapes where even the best land for agriculture is exceptionally good habitat for species.

Finally, we modelled a system where species capacity was lower than agricultural capacity for high value parcels, but species capacity was higher than agricultural capacity when capacity is lower. That is $\lambda_{i j}<r_{i}$ until $N_{1}$ at which point $\lambda_{i j}>r_{i}$. We called this case species negative and it can be represented as.

$$
\begin{array}{ll}
\lambda_{i j}<r_{i}, & \forall(i, j) \in\left[1, N_{1}\right] \mathrm{x}[1, J] \\
\lambda_{i j}>r_{i}, & \forall(i, j) \in\left[N_{1}, N\right] \mathrm{x}[1, J]
\end{array}
$$

This would be the case where the best land for agriculture is exceptionally good, relative to carrying capacity for species.

In all of these cases except reverse, there was a positive relationship between species capacity and agricultural capacity: areas that were better for agriculture were also better for biodiversity. What varied though was the shape of this relationship across different levels of capacity. We largely omitted negative relationships between species capacity and agricultural capacity, because these would be areas of minimal conflict between agricultural production and conservation. The solution in these landscapes (as illustrated with the reverse case) may be the same as we would see in a market system where the costs of biodiversity loss are not considered. Agriculture would be directed to the land with highest capacity for agriculture and the most productive lands for species conservation would remain untouched. 


\section{Optimizing heterogeneous landscapes with multiple target species and many parcels}

We used an interior point algorithm, a constrained optimization technique, to find landscapes that minimized trade-offs between total agricultural production and species' total abundance at the landscape scale for landscapes with 100 parcels, arranged in a 10 x 10 grid, and with multiple species. We framed our problem as follows. We aimed to maximize agricultural production $\boldsymbol{X}$ on a landscape, with the constraint that each species $\boldsymbol{j}$ on the landscape must be maintained at a certain population $\boldsymbol{\tau}$. The functional relationships between species' abundance and agricultural intensity as well as agricultural production and agricultural intensity were described by equation 2 . In this specification, each species had to meet a specified population target, and given that these targets were met, production was then maximized. This framing is in line with major environmental laws such as the Endangered Species Act in the United States of America (NOAA 2016), where farmers are allowed to maximize production, given there are limited negative impacts on endangered species.

Given the functions used in our models, our objective translates into

$$
\max X \text { s.t. } \mathrm{n}_{\mathrm{j}}>\tau_{j} \forall j
$$

where $\tau$ was a target population for each species.

We optimized land-use for a total of 24 scenarios. We used six previously described relationships between agricultural capacity and species capacity and tested each relationship for three species assemblages: 1) nine sharing species, 2) nine sparing species and 3) and an empirical example from Kamp et al. 2015. For the empirical example, we solve the optimization for both the maximum population and natural habitat baselines. The optimizations were performed in MATLAB using the $f$ mincon function in the optimization toolbox and the interior point algorithm. We maximized total agricultural production for species targets equal to 40 percent of each species reference population. That is, in all solutions each species maintained a population size at least $40 \%$ of its reference population. There are compelling reasons to suspect that no single population target is likely to apply adequately to all populations because extinction risks are often context dependent, and manifest from a complex interaction between life history, ecological interactions, environmental setting and threats (Flather et al. 2011). For example, previous studies have considered 30\% populations as minimum target (Law et al. 2015), while the Convention on Biological Diversity proposes a 17\% area-

This article is protected by copyright. All rights reserved 
protection goal. Ultimately, population are species specific, and should be representative of the conservation status of the considered species.

In addition to finding the optimal solution for each landscape, we also calculated how much production is gained when using the optimization method instead of pure sparing or sharing strategy. All MATLAB code as well as an intuitive description of how the model is solved is available in Appendix S1.

\section{Results}

\section{Case 1. Homogenous land capacity}

When land capacity was homogenous across the landscapes, our results confirm the results of classic sparing vs. sharing studies, which typically assumed homogeneous landscapes. If all species had convex relationships between agricultural intensity and species' populations (assemblage 1: sparing species), total, landscape-level production was maximized if agriculture was carried out at high intensity on as few as possible parcels, and other parcels are left out of production. For sharing species (assemblage 2), production was maximized if agriculture was spread evenly throughout the landscape at lower intensities. For the third assemblage of mixed species, a strategy where some parcels were used at less than full intensity and others were not used at all was optimal (i.e., resulted in the lowest trade-offs between total agricultural production and total species abundance, Figure 3, column 1, Table 2), when the maximum population baseline was used. When the natural habitats baseline was used, a sparing landscape was optimal. This is in line with our earlier work (Butsic \& Kuemmerle 2015) although we here use empirical functional forms of the intermediate species compared to the simulated functional forms in our prior paper.

\section{Case 2. Agricultural heterogeneity}

When agricultural capacity was heterogeneous across the landscape, we found major changes compared to Case 1. For the sparing assemblage, agricultural production was concentrated on highproductive land, and at maximum agricultural intensity. For the sharing assemblage, production was concentrated on high-capacity land, with lesser amounts of low-capacity land used as well. Interestingly though, unlike in the case of the homogenous landscape, agricultural intensity in our 
optimal landscape was not evenly distributed throughout. Some parcels had high-intensity agriculture, and some low. Finally, for the species assemblage where all three types of species were present, agriculture in the optimal landscape was focused on the most productive land, and varied intensity across the landscape (Figure 3, column 2, Table 2).

\section{Case 3. Proportional relationship between agricultural capacity and species capacity}

When agricultural capacity and species capacity increased proportionally, heterogeneity in the landscape did not change the optimal land-use strategy as compared to Case 1. For the species assemblage featuring only sparing species, parcels were either used at the highest agricultural intensity possible or not at all. For the assemblage featuring only sharing species, all parcels were used at medium agricultural intensity. The mixed assemblage featured aspects of both sharing and sparing landscapes for the maximum population baseline: some parcels were not used at all, while others were used, but not at their maximum intensity. For the natural habitat baseline, a sparing landscape was found. Because changes in capacity influence yields and species populations proportionally, the total agricultural production changed from the homogenous case, but the optimal strategy was similar (Figure 3 column 3, Table 2).

\section{Case 4. Reverse}

When there was a negative relationship between agricultural and species capacity, agriculture in the optimal landscape always took place in the highest-yielding agricultural parcels. For the sparing assemblage, landscapes minimizing trade-offs between agricultural production and biodiversity had all agricultural production focusing on those parcels with the highest agricultural capacity, at highest possible intensity. For the sharing assemblage, optimal landscapes had high agricultural intensity on high-capacity land and lower intensity elsewhere. For the mixed species assemblage, the optimal landscape had both high and low agricultural intensity parcels for the maximum population baseline and a sparing landscape for a natural habitat baseline (Figure 3 column 4, Table 2).

\section{Case 5. Species positive relationship between agricultural capacity and species capacity}


When assuming a positive relationship between agricultural and species capacity, agricultural production was focused on the highest yielding parcels. For the sparing assemblage, this resulted in the same landscape as in the homogenous (i.e., classic) case, where parcels were used at full intensity or not at all. For the sharing assemblage, the optimal landscape differed markedly from the classic sharing landscape, as some parcels were left undeveloped, whereas other parcels were used at varying intensity. Finally, when the maximum population baseline was used the optimal landscape for the mixed assemblage had attributes of sparing and sharing landscapes, and agriculture primarily took place in the areas with the highest agricultural capacity (Figure 3 column 5, Table 2). For the natural habitat baseline a sparing landscape was found. In all cases, there is a tendency to produce agriculture on low-productivity lands.

\section{Case 6. Species negative relationship between agricultural capacity and species capacity}

Assuming a negative relationship between agricultural capacity and species capacity resulted in an optimal landscape where production was concentrated on the lowest-yielding parcels. For the sparing assemblage, this resulted in a classic sparing landscape, where parcels were either used to their maximum intensity or not at all. For the sharing assemblage, our results differed from the classic sharing landscape, as some parcels were left undeveloped, and others were used at varying intensity. Finally, the optimal landscape for the mixed assemblage was a mix of medium-intensity and lowintensity agricultural use (Figure 3 column 6, Table 2) for the maximum population baseline and a sparing landscape for the natural habitat baseline. In all cases, there was a tendency to produce agriculture on high productivity lands.

\section{The cost of forcing pure sharing or sparing strategies instead of a mixed strategy}

Our results allow us to see the difference in potential agricultural production between using sparing and sharing strategies, versus a mixed strategy that was most often more optimal in our analyses. When we apply a pure sparing strategy, the objective function is never satisfied. That is, no solution can be found using this strategy. This is because no parcels were used at intermediate levels, which is where some species thrive best, and therefore these species never met the $40 \%$ threshold. Using a pure sharing strategy on heterogeneous parcels is likewise a poor strategy. In our case, this resulted on 
average in a $24 \%$ reduction in agricultural output when forcing a sharing strategy as opposed to the truly optimal strategy across all heterogeneous landscapes (Table 1).

\section{The importance of maximum population baselines}

Assumptions about how to define the maximum population per species had substantial effects on the resulting strategy to maximize biodiversity and agricultural production. When using the maximum population baseline, a large number of cells were used at medium intensity when intermediate species were present (at least $37 \%$ of cells were used at a medium intensity; Table 2). This is because, when cells were used at either zero or 100\% intensity, intermediate species have very low populations and therefore to preserve all species at least some of the landscape must be used at intermediate intensity. However, using the natural habitat baseline we found results very similar to a sparing landscape (Table 2). This is because under this assumption, differences between intermediate and sparing are small, with decreases in population starting at higher land use intensities.

\section{Discussion}

Harmonizing agricultural production and biodiversity conservation has emerged as one of the greatest sustainability challenges of the $21^{\text {st }}$ century (Chappell \& LaValle 2009; Tilman et al. 2011; Kehoe et al. 2017). Past research has generally focused on how biodiversity responds to land-use intensity (Newbold et al. 2015, 2016), and how to use this knowledge to suggest strategies for landscape design (Phalan et al. 2011; Macchi et al. 2013). Yet, existing work to date has largely ignored that real-world landscapes are not homogeneous in their land capacity. Here, we show how heterogeneous landscapes can be managed to maximize agricultural production while maintaining species populations. We expand on past analyses (Butsic \& Kuemmerle 2015) to include landscapes with different relationships between agricultural and species capacities, and to incorporate empirical

data to characterize intermediate species. The results of our models suggest that pure land sparing and land sharing strategies are rarely optimal unless one reference populations always take place when land-use intensity is equal to zero. Based on these results we suggest rules of thumb that can be applied widely when thinking about how to manage landscapes to minimize trade-offs between agricultural production and biodiversity.

This article is protected by copyright. All rights reserved 
First, conservation with the goal to safeguard species' populations should focus on areas where species capacity has a comparative advantage over agricultural capacity. This does not mean that conservation should take place only on the areas with the highest populations. Rather conservation should take place in those areas where the positive difference between species capacity and agricultural capacity is maximized. Counterintuitively, this means that sometimes biodiversity and agricultural production trade-offs are minimized when agriculture is carried out at high intensity on low capacity land. That is, instead of maximizing yield on areas of high production to minimize total land-use extent, it is sometimes better to use areas of low productive capacity at high agricultural intensity, if areas of high agricultural productivity have very high species productivity as well. Such situations can arise where species populations are highest on the areas that are most productive, a pattern that may be common globally (Clough et al. 2011; Cusens et al. 2012).

This insight is useful for land-use and conservation planning alike and is in line with other conservation planning approaches that minimize opportunity cost and maximize return on investment (Naidoo \& Adamowicz 2006; Goldstein et al. 2008). Most of the world's most fertile agricultural areas, such as riverine floodplains, deltas, or black earth regions are today used intensively for agricultural production (Ellis et al. 2013) producing among the world's highest yields. Our results provide a cautionary note regarding the potential biodiversity trade-off of agriculture in these regions. Although a focus on the most fertile and productive regions minimizes the land area required for a given production goal, it may in fact not minimize the trade-off between agricultural production and biodiversity conservation (Figure 3, column 5). A policy that focuses agriculture on the most fertile lands may be sub-optimal if these places are even more fertile for species.

Moreover, agricultural capacity may also change quickly and dramatically. For example, areas that are water-limited may have very low agricultural capacity, but the introduction of rainwater harvesting or irrigation can raise this capacity many times over. Likewise, the agricultural capacity of areas which are nitrogen limited can be lifted through the use of fertilizers. Our results suggest that in the long term, in some situations, the best way to meet the needs of agriculture and biodiversity may be to conserve at least some of the land with highest capacity for biodiversity conservation, and use lower capacity land for agricultural production, while developing farming techniques to maximize yield on such lower-capacity lands. It might therefore be beneficial for the conservation community to 
engage with those working to grow food on less fertile grounds, especially where this land has little biodiversity value, or to engage in the restoration of marginal lands (Evans et al. 2015). Obviously, any strategy to shift agricultural production into more marginal lands (those with low yields) for agriculture requires careful consideration of possible short-term and long-term land-degradation outcomes.

Notably, when agricultural capacity and species capacity are proportional, our findings for heterogeneous landscapes are the same as previous findings for homogenous landscapes. That is, a pure land sparing strategy minimizes trade-offs when only land sparing species are present, and a sharing strategy is best when only sharing species are present. In heterogeneous and homogeneous landscapes, when sparing, sharing, and intermediate species are jointly present, the best strategy depends on how the reference population is defined. Such a mixed assemblage of species is almost always the case in real-world situations; in fact, we know of no study that assessed yield/density curves that did not have at least some intermediate species (Phalan et al. 2011; Mastrangelo \& Gavin 2012; Hulme et al. 2013; Macchi et al. 2013; Dotta et al. 2017; Williams et al. 2017). This suggests that to date, there is no empirical basis for suggesting that a pure sparing or sharing strategy is optimal to conserve all species unless one is acting under the assumption that the relevant reference population occurs when land use intensity is zero.

The issue of what spatial scale (i.e. what extent and resolution) is most appropriate is an important question for any model. In our case, we suggest the appropriate spatial extent for our model is the extent for which targets for conservation planning are set in order to protect, maintain or restore threatened species' populations. This differs substantially across the globe, due to diverse species' ecology and biogeography, different environmental settings, and different institutional setups. For some species, population goals might best be set at the country level, for other species, population goals may be relevant on ecoregional scales or on an individual farm. As for spatial resolution, in our case the size of individual cells, we suggest the best resolution is the size of a management unit at which a population can be influenced. Again, this will vary depending on the species of interest. Mathematically, our model is agnostic to questions of extent and resolution and works regardless of the size and number of spatial cells or the extent of the landscape. Of course, as the number of cells increases (as would be likely at larger extents) the computational effort increases.

This article is protected by copyright. All rights reserved 
We found that the decisions about how to define the reference population, specifically where along the land-use intensity gradient it occurs, has considerable impacts. When intermediate species have reference populations in natural habitat that has zero land-use intensity, the optimal landscape moves towards a land sparing landscape. This result is not surprising given past theoretical work showing that in the absence of intermediate species, sparing landscapes are optimal (Butsic and Kuemmerle 2015). When the reference population occurs at their empirically-observed maximum, which is often not natural habitat, we found that landscapes had some medium-intensity use parcels. This is because species with intermediate responses require such parcels to meet population targets. Both methods to set reference populations can be justified, but allowing for population maxima occurring along the gradient of land-use intensity seems especially warranted where disturbancedependent species or farmland biodiversity are of conservation concern.

As with all modeling exercises, our model does not address all potential facets of complex human-environment interactions. First, each species is given equal weight in our models, and in the case where a manager chooses a number of species of equal importance, this may be a good assumption. However, if species differ in the size of their home ranges, a weighting scheme may be appropriate. Likewise, weighting endemics over non-endemic species might be appropriate. Second, an omission of our model is the lack of spatial spillovers from one cell to another, which would make the arrangement of landscape heterogeneity important (Lamb et al. 2016). In instances where populations are dependent on individuals moving across cells, the spatial arrangement would impact on population dynamics and viability. Third, our choice of optimization methods precludes the important issues of food security, food sovereignty, and food justice; issues which may be of equal importance as simply the amount of agricultural commodities produced. Likewise, the amount of food produced is just one potential factor to be maximized. For instance, food quality, nutrient composition or minimizing pesticide residues may also be worthwhile goals. Indeed, the very fact that we optimize across only two variables (production and biodiversity) leaves out many important dimensions that could be worthwhile to consider when aligning agriculture and biodiversity, such as human health and pollution. Finally, we acknowledge that even though adding landscape heterogeneity to our model is an improvement over past models, it still leaves out many potentially important dynamics such as species population dynamics, habitat connectivity, interactions between species, climate change 
mitigation corridors, land degradation, and feedbacks between food production and food demand. Finally, our model does not account for the potential for biodiversity itself to impact yields. While prominent examples have been recently report, especially for the case of bees and pollination (Garibaldi et al. 2014), this important component is left out primarily because the functional form of this relationship has rarely quantified empirically and is taxa dependent (Bommarco et al. 2013), although including this feedback in future work is a priority. Proxies of these desired-objectives could be integrated in optimization exercises, where specific targets for each of them would further constrain the analysis.

Landscapes are often heterogeneous in their capacity to produce agricultural output and biodiversity, and our model demonstrates that considering landscape heterogeneity can lead to useful and at times unintuitive results. For example, the assumption that farming is best for biodiversity when it uses the most productive land may be problematic if that land is also valuable for species. Similarly, our work highlights that in real-world situations with varying land capacity, oftentimes neither pure sparing nor pure sharing strategies are the most beneficial to create co-benefits between agriculture and biodiversity, unless one assumes that reference populations of species take place when land use intensity is equal to zero. The relationship between land capacity for agriculture and biodiversity requires further research efforts. It may well be the case that this relationship is variable across landscapes and scales. Understanding the land capacity relationship is a needed step to assessing the tradeoffs between agriculture and biodiversity to optimize landscapes, with several successful applications now showing the power of such approaches (Polasky et al. 2005, 2008; Law et al. 2017). More generally, we suggest a land management path that addresses not only the intensity at which we should farm, but also focuses on finding areas that produce highest yield with the lowest harm.

This article is protected by copyright. All rights reserved 


\section{Acknowledgements}

This work was supported by the Alexander von Humboldt Foundation (V.B., T.K., LM.) and the Einstein Foundation Berlin (T.K.). We thank the editor Dr. Nelson and four reviewers for several rounds of constructive and helpful comments that improved this manuscript.

\section{References}

Anand, M.O., Krishnaswamy, J., Kumar, A. \& Bali, A. (2010). Sustaining biodiversity conservation in human-modified landscapes in the Western Ghats: Remnant forests matter. Biol. Conserv., $143,2363-2374$.

Bajželj, B., Richards, K.S., Allwood, J.M., Smith, P., Dennis, J.S., Curmi, E. \& Gilligan, C.A. (2014). Importance of food-demand management for climate mitigation. Nat. Clim. Chang., 4, 924-929.

Bommarco, R., Kleijn, D. \& Potts, S.G. (2013). Ecological intensification: harnessing ecosystem services for food security. Trends Ecol. Evol., 28, 230-238.

Butsic, V. \& Kuemmerle, T. (2015). Using optimization methods to align food production and biodiversity conservation beyond land sharing and land sparing. Ecol. Appl., 25, 589-595.

Chappell, M.J. \& LaValle, L.A. (2009). Food security and biodiversity: can we have both? An agroecological analysis. Agric. Human Values, 28, 3-26.

Clough, Y., Barkmann, J., Juhrbandt, J., Kessler, M., Wanger, T.C., Anshary, A., Buchori, D., Cicuzza, D., Darras, K., Putra, D.D., Erasmi, S., Pitopang, R., Schmidt, C., Schulze, C.H., Seidel, D., Steffan-Dewenter, I., Stenchly, K., Vidal, S., Weist, M., Wielgoss, A.C. \& Tscharntke, T. (2011). Combining high biodiversity with high yields in tropical agroforests. Proc. Natl. Acad. Sci., 108, 8311-8316.

Cusens, J., Wright, S.D., McBride, P.D. \& Gillman, L.N. (2012). What is the form of the productivity-animal-species-richness relationship? A critical review and meta-analysis. Ecology, 93, 2241-2252.

This article is protected by copyright. All rights reserved 
Donald, P.F., Sanderson, F.J., Burfield, I.J. \& van Bommel, F.P.J. (2006). Further evidence of continent-wide impacts of agricultural intensification on European farmland birds, 1990-2000. Agric. Ecosyst. Environ., 116, 189-196.

Dotta, G., Phalan, B., Silva, T.W., Green, R. \& Balmford, A. (2017). Assessing strategies to reconcile agriculture and bird conservation in the temperate grasslands of South America. Conserv. Biol., $30,618-627$.

Ellis, E.C., Kaplan, J.O., Fuller, D.Q., Vavrus, S., Klein Goldewijk, K. \& Verburg, P.H. (2013). Used planet: a global history. Proc. Natl. Acad. Sci. U. S. A., 110, 7978-85.

Erb, K.-H., Lauk, C., Kastner, T., Mayer, A., Theurl, M.C. \& Haberl, H. (2016). Exploring the biophysical option space for feeding the world without deforestation. Nat. Commun., 7, 11382.

Evans, S.G., Ramage, B.S., DiRocco, T.L. \& Potts, M.D. (2015). Greenhouse Gas Mitigation on Marginal Land: A Quantitative Review of the Relative Benefits of Forest Recovery versus Biofuel Production. Environ. Sci. Technol., 49, 2503-2511.

Fischer, J., Abson, D.J.D.J., Butsic, V., Chappell, M.J.J., Ekroos, J., Hanspach, J., Kuemmerle, T., Smith, H.G.H.G. \& von Wehrden, H. (2014). Land sparing versus land sharing: moving forward. Conserv. Lett., 7, 149-157.

Flather, C.H., Hayward, G.D., Beissinger, S.R. \& Stephens, P.A. (2011). Minimum viable populations: is there a 'magic number' for conservation practitioners? Trends Ecol. Evol., 26, $307-316$.

Godfray, H.C.J. (2011). Ecology. Food and biodiversity. Science, 333, 1231-2.

Goldstein, J.J.H., Pejchar, L. \& Daily, G.C.G. (2008). Using return-on-investment to guide restoration: a case study from Hawaii. Conserv. Lett., 1, 236-243.

Grau, R., Kuemmerle, T. \& Macchi, L. (2013). Beyond 'land sparing versus land sharing': environmental heterogeneity, globalization and the balance between agricultural production and nature conservation. Curr. Opin. Environ. Sustain., 5, 477-483.

This article is protected by copyright. All rights reserved 
Green, R.E., Cornell, S.J., Scharlemann, J.P.W. \& Balmford, A. (2005). Farming and the Fate of Wild Nature. Science (80-. )., 307, 550-555.

Hanberry, B.B. (2014). Decreases by disturbance-dependent tree species in the eastern and central USA. Eur. J. For. Res., 133, 1029-1041.

Hulme, M.F., Vickery, J.A., Green, R.E., Phalan, B., Chamberlain, D.E., Pomeroy, D.E., Nalwanga, D., Mushabe, D., Katebaka, R., Bolwig, S. \& Atkinson, P.W. (2013). Conserving the Birds of Uganda's Banana-Coffee Arc: Land Sparing and Land Sharing Compared. PLoS One, 8, e54597.

Kamp, J., Urazaliev, R., Balmford, A., Donald, P.F., Green, R.E., Lamb, A.J. \& Phalan, B. (2015). Agricultural development and the conservation of avian biodiversity on the Eurasian steppes: a comparison of land-sparing and land-sharing approaches. J. Appl. Ecol., 52, 1578-1587.

Kehoe, L., Kuemmerle, T., Meyer, C., Levers, C., Václavík, T. \& Kreft, H. (2015). Global patterns of agricultural land-use intensity and vertebrate diversity. Divers. Distrib., 21, 1308-1318.

Kehoe, L., Romero-Muñoz, A., Polaina, E., Estes, L., Kreft, H. \& Kuemmerle, T. (2017). Biodiversity at risk under future cropland expansion and intensification. Nat. Ecol. Evol., 1, 1129-1135.

Kleijn, D., Kohler, F., Báldi, A., Batáry, P., Concepción, E.., Clough, Y., Díaz, M., Gabriel, D., Holzschuh, A., Knop, E., Kovács, A., Marshall, E.J.., Tscharntke, T. \& Verhulst, J. (2009). On the relationship between farmland biodiversity and land-use intensity in Europe. Proc. R. Soc. London B Biol. Sci., 276.

Kremen, C. (2015). Reframing the land-sparing/land-sharing debate for biodiversity conservation. Ann. N. Y. Acad. Sci., 1355, 52-76.

Kremen, C., Cameron, A., Moilanen, A., Phillips, S.J., Thomas, C.D., Beentje, H., Dransfield, J., Fisher, B.L., Glaw, F., Good, T.C., Harper, G.J., Hijmans, R.J., Lees, D.C., Louis, E., Nussbaum, R.A., Raxworthy, C.J., Razafimpahanana, A., Schatz, G.E., Vences, M., Vieites, D.R., Wright, P.C. \& Zjhra, M.L. (2008). Aligning Conservation Priorities Across Taxa in Madagascar with High-Resolution Planning Tools. Science (80-. )., 320.

This article is protected by copyright. All rights reserved 
Lamb, A., Balmford, A., Green, R.E. \& Phalan, B. (2016). To what extent could edge effects and habitat fragmentation diminish the potential benefits of land sparing? Biol. Conserv., 195, 264271.

Lambin, E.F.E. \& Meyfroidt, P. (2011). Global land use change, economic globalization, and the looming land scarcity. Proc. Natl. Acad. Sci. U. S. A., 108, 3465-3472.

Law, E.A., Bryan, B.A., Meijaard, E., Mallawaarachchi, T., Struebig, M.J., Watts, M.E. \& Wilson, K.A. (2017). Mixed policies give more options in multifunctional tropical forest landscapes. $J$. Appl. Ecol., 54, 51-60.

Law, E.A., Meijaard, E., Bryan, B.A., Mallawaarachchi, T., Koh, L.P. \& Wilson, K.A. (2015). Better land-use allocation outperforms land sparing and land sharing approaches to conservation in Central Kalimantan, Indonesia. Biol. Conserv., 186, 276-286.

Macchi, L., Grau, H.R., Zelaya, P. V. \& Marinaro, S. (2013). Trade-offs between land use intensity and avian biodiversity in the dry Chaco of Argentina: A tale of two gradients. Agric. Ecosyst. Environ., 174, 11-20.

Margules, C.R. \& Pressey, R.L.R. (2000). Systematic conservation planning. Nature, 405, $243-253$.

Mastrangelo, M. \& Laterra, P. (2015). From biophysical to social-ecological trade-offs: integrating biodiversity conservation and agricultural production in the Argentine Dry Chaco. Ecol. Soc., 20.

Mastrangelo, M.E. \& Gavin, M.C. (2012). Trade-Offs between Cattle Production and Bird Conservation in an Agricultural Frontier of the Gran Chaco of Argentina. Conserv. Biol., 26, $1040-1051$.

Metrick, A. \& Weitzman, M.L. (1998). Conflicts and Choices in Biodiversity Preservation. J. Econ. Perspect., 12, 21-34.

Moilanen, A. \& Arponen, A. (2011). Setting conservation targets under budgetary constraints. Biol. Conserv., 144, 650-653.

Naidoo, R. \& Adamowicz, W.L. (2006). Modeling opportunity costs of conservation in transitional 
landscapes. Conserv. Biol., 20, 490-500.

Newbold, T., Hudson, L.N., Hill, S.L.L., Contu, S., Gray, C.L., Scharlemann, J.P.W., Börger, L., Phillips, H.R.P., Sheil, D., Lysenko, I. \& Purvis, A. (2016). Global patterns of terrestrial assemblage turnover within and among land uses. Ecography (Cop.)., 39, 1151-1163.

Newbold, T., Hudson, L.N., Hill, S.L.L., Contu, S., Lysenko, I., Senior, R.A., Börger, L., Bennett, D.J., Choimes, A., Collen, B., Day, J., De Palma, A., Díaz, S., Echeverria-Londoño, S., Edgar, M.J., Feldman, A., Garon, M., Harrison, M.L.K., Alhusseini, T., Ingram, D.J., Itescu, Y., Kattge, J., Kemp, V., Kirkpatrick, L., Kleyer, M., Correia, D.L.P., Martin, C.D., Meiri, S., Novosolov, M., Pan, Y., Phillips, H.R.P., Purves, D.W., Robinson, A., Simpson, J., Tuck, S.L., Weiher, E., White, H.J., Ewers, R.M., Mace, G.M., Scharlemann, J.P.W. \& Purvis, A. (2015). Global effects of land use on local terrestrial biodiversity. Nature, 520, 45-50.

NOAA. (2016). Endangered Species Act (ESA) :: NOAA Fisheries.

Perfecto, I. \& Vandermeer, J. (2010). The agroecological matrix as alternative to the landsparing/agriculture intensification model. Proc. Natl. Acad. Sci. U. S. A., 107, 5786-5791.

Phalan, B., Onial, M., Balmford, A. \& Green, R.E. (2011). Reconciling food production and biodiversity conservation: land sharing and land sparing compared. Science, 333, 1289-91.

Polasky, S., Nelson, E., Camm, J., Csuti, B., Fackler, P., Lonsdorf, E., Montgomery, C., White, D., Arthur, J., Garber-Yonts, B., Haight, R., Kagan, J., Starfield, A. \& Tobalske, C. (2008). Where to put things? Spatial land management to sustain biodiversity and economic returns. Biol. Conserv., 141, 1505-1524.

Polasky, S., Nelson, E., Lonsdorf, E., Fackler, P. \& Starfield, A. (2005). Conserving species in a working landscape: Land use with biological and economic objectives. Ecol. Appl., 15, 13871401.

Pywell, R.F., Heard, M.S., Bradbury, R.B., Hinsley, S., Nowakowski, M., Walker, K.J. \& Bullock, J.M. (2012). Wildlife-friendly farming benefits rare birds, bees and plants. Biol. Lett., 8, 772775.

This article is protected by copyright. All rights reserved 
Seppelt, R., Beckmann, M., Ceauşu, S., Cord, A.F., Gerstner, K., Gurevitch, J., Kambach, S., Klotz, S., Mendenhall, C., Phillips, H.R.P., Powell, K., Verburg, P.H., Verhagen, W., Winter, M. \& Newbold, T. (2016). Harmonizing Biodiversity Conservation and Productivity in the Context of Increasing Demands on Landscapes. Bioscience, 111, biw004.

Tilman, D., Balzer, C., Hill, J. \& Befort, B.L. (2011). Global food demand and the sustainable intensification of agriculture. Proc. Natl. Acad. Sci. U. S. A., 108, 20260-4.

Tscharntke, T., Clough, Y., Wanger, T.C., Jackson, L., Motzke, I., Perfecto, I., Vandermeer, J. \& Whitbread, A. (2012). Global food security, biodiversity conservation and the future of agricultural intensification. Biol. Conserv., 151, 53-59.

Tsiafouli, M.A., Thébault, E., Sgardelis, S.P., de Ruiter, P.C., van der Putten, W.H., Birkhofer, K., Hemerik, L., de Vries, F.T., Bardgett, R.D., Brady, M.V., Bjornlund, L., Jørgensen, H.B., Christensen, S., Hertefeldt, T.D., Hotes, S., Gera Hol, W.H., Frouz, J., Liiri, M., Mortimer, S.R., Setälä, H., Tzanopoulos, J., Uteseny, K., Pižl, V., Stary, J., Wolters, V. \& Hedlund, K. (2015). Intensive agriculture reduces soil biodiversity across Europe. Glob. Chang. Biol., 21, 973-985.

Uchida, K. \& Ushimaru, A. (2014). Biodiversity declines due to abandonment and intensification of agricultural lands: patterns and mechanisms. Ecol. Monogr., 84, 637-658.

Wiens, J.A. (1989). The ecology of bird communities. Cambridge University Press.

Williams, D.R., Alvarado, F., Green, R.E., Manica, A., Phalan, B. \& Balmford, A. (2017). Land-use strategies to balance livestock production, biodiversity conservation and carbon storage in Yucatán, Mexico. Glob. Chang. Biol., 23, 5260-5272.

Wilson, K.A.K.A., Meijaard, E., Drummond, S., Grantham, H.S.H., Boitani, L., Catullo, G., Christie, L., Dennis, R., Dutton, I., Falcucci, A., Maiorano, L., Possingham, H.P., Rondinini, C., Turner, W.R., Venter, O. \& Watts, M. (2010). Conserving biodiversity in production landscapes. Ecol. Appl., 20, 1721-1732.

Wright, H.L., Lake, I.R. \& Dolman, P.M. (2012). Agriculture-a key element for conservation in the developing world. Conserv. Lett., 5, 11-19.

This article is protected by copyright. All rights reserved 
Table 1. Comparison of production when species target of $10 \%$ of maximum population is maintained under optimal landscape configuration, sparing configuration and sharing configuration for various types of landscapes and the empirical species assemblage. Maximum production is 100 in all landscapes when no species are conserved.

\begin{tabular}{|l|l|l|l|l|l|l|}
\hline & \multicolumn{3}{|l|}{ Relationship between landscape capacity and species capacity } \\
\hline & $\begin{array}{l}\text { Homo- } \\
\text { genous }\end{array}$ & $\begin{array}{l}\text { Ag. } \\
\text { Heterogeneity }\end{array}$ & Proportional & Reverse & $\begin{array}{l}\text { Species } \\
\text { Positive }\end{array}$ & $\begin{array}{l}\text { Species } \\
\text { Negative }\end{array}$ \\
\hline $\begin{array}{l}\text { Optimization } \\
\text { with } \\
\begin{array}{l}\text { Maximum } \\
\text { Population } \\
\text { baseline }\end{array}\end{array}$ & 47.1 & 35.4 & 25.5 & 43.2 & 26.5 & 26.4 \\
\hline $\begin{array}{l}\text { Optimization } \\
\text { with Natural } \\
\text { Habitat } \\
\text { Baseline }\end{array}$ & 60.4 & 43.9 & 32.7 & 49.8 & 34.1 & 33.9 \\
\hline $\begin{array}{l}\text { Production } \\
\text { using land } \\
\text { sharing } \\
\text { method } \\
\text { (Maximum } \\
\text { population } \\
\text { baseline) }\end{array}$ & $\begin{array}{l}\text { No solution } \\
\text { possible }\end{array}$ & $\begin{array}{l}\text { No solution } \\
\text { possible }\end{array}$ & $\begin{array}{l}\text { No solution } \\
\text { possible }\end{array}$ & $\begin{array}{l}\text { No } \\
\text { solution } \\
\text { possible }\end{array}$ & $\begin{array}{l}\text { No } \\
\text { solution } \\
\text { possible }\end{array}$ & $\begin{array}{l}\text { solution } \\
\text { possible }\end{array}$ \\
\hline $\begin{array}{l}\text { Production } \\
\text { using land }\end{array}$ & 27.5 & 13.8 & 13.8 & 13.8 & 13.8 & 13.8 \\
\hline
\end{tabular}




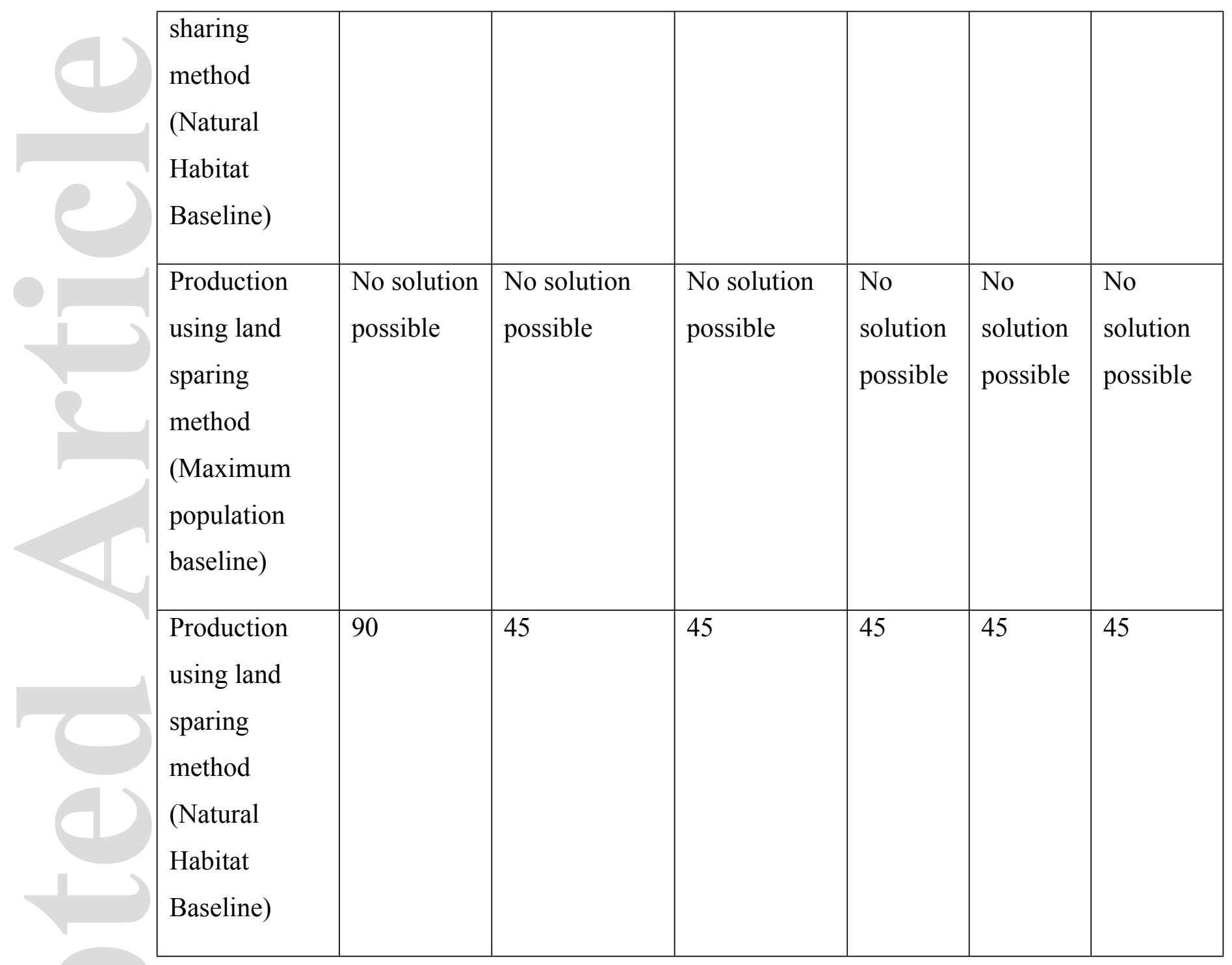


Table 2. Number of cells spared (i.e., land-use intensity $<0.01$ ), number of cells shared (land-use intensity between 0.01 and 0.99 ) and number of cells developed (land-use intensity $>0.99$ ) in optimizations with $40 \%$ of each species maintained on the landscape.

\begin{tabular}{|c|c|c|c|c|c|c|c|}
\hline & & Homogenous & $\begin{array}{l}\mathrm{Ag} \\
\text { Heterogeneity }\end{array}$ & Proportional & Reverse & $\begin{array}{l}\text { Species } \\
\text { Positive }\end{array}$ & $\begin{array}{l}\text { Species } \\
\text { Negative }\end{array}$ \\
\hline \multirow[t]{4}{*}{ All Sparing } & $\begin{array}{l}\text { Number of spared } \\
\text { cells }\end{array}$ & 43 & 43 & 49 & 26 & 45 & 48 \\
\hline & $\begin{array}{l}\text { Number of shared } \\
\text { cells }\end{array}$ & 1 & 1 & 1 & 1 & 0 & 0 \\
\hline & $\begin{array}{l}\text { Number of } \\
\text { developed cells }\end{array}$ & 56 & 56 & 50 & 73 & 55 & 52 \\
\hline & Total production & 56 & 39 & 26 & 46 & 28 & 29 \\
\hline \multirow[t]{4}{*}{ All Sharing } & $\begin{array}{l}\text { Number of spared } \\
\text { cells }\end{array}$ & 0 & 3 & 0 & 2 & 0 & 0 \\
\hline & $\begin{array}{l}\text { Number of shared } \\
\text { cells }\end{array}$ & 100 & 52 & 100 & 27 & 96 & 100 \\
\hline & $\begin{array}{l}\text { Number of } \\
\text { developed cells }\end{array}$ & 0 & 45 & 0 & 71 & 4 & 0 \\
\hline & Total production & 72 & 43 & 37 & 48 & 37 & 38 \\
\hline \multirow{4}{*}{$\begin{array}{l}\text { Empirical } \\
\text { (Maximum } \\
\text { Population } \\
\text { Baseline) }\end{array}$} & $\begin{array}{l}\text { Number of spared } \\
\text { cells }\end{array}$ & 40 & 40 & 42 & 25 & 52 & 51 \\
\hline & $\begin{array}{l}\text { Number of shared } \\
\text { cells }\end{array}$ & 45 & 40 & 47 & 37 & 37 & 37 \\
\hline & $\begin{array}{l}\text { Number of } \\
\text { developed cells }\end{array}$ & 15 & 20 & 11 & 38 & 11 & 12 \\
\hline & Total production & 47.1 & 35.4 & 25.5 & 43.2 & 26.5 & 26.4 \\
\hline \multirow{3}{*}{$\begin{array}{l}\text { Empirical } \\
\text { (Natural } \\
\text { Habitat } \\
\text { Baseline) }\end{array}$} & $\begin{array}{l}\text { Number of spared } \\
\text { cells }\end{array}$ & 40 & 40 & 38 & 24 & 53 & 57 \\
\hline & $\begin{array}{l}\text { Number of shared } \\
\text { cells }\end{array}$ & 0 & 0 & 1 & 1 & 1 & 0 \\
\hline & $\begin{array}{l}\text { Number of } \\
\text { developed cells }\end{array}$ & 60 & 60 & 61 & 75 & 46 & 43 \\
\hline
\end{tabular}

This article is protected by copyright. All rights reserved 


\begin{tabular}{|l|l|l|l|l|l|l|}
\hline & Total production & 60.4 & 43.9 & 32.7 & 49.8 & 34.1 \\
\hline
\end{tabular}

This article is protected by copyright. All rights reserved 


\section{List of figures}

Figure 1. Relationship between land-use intensity and species abundance for the empirical example. Figure A uses the maximum population method to find the maximum population. Figure B uses the natural habitat method. Note that in figure A the there are two intermediate curves that become sparing curves in figure B.

Figure 2. Landscapes depicting six relationships between agricultural capacity and species capacity. Darker colors indicate higher capacity, lighter values lower capacity. To make the relationships between agricultural capacity and species capacity easier to visualize, we have arranged the parcels with highest capacity agriculture in the lower right-hand corner. The results of the optimization is not dependent on the spatial arrangement of the parcels.

Figure 3. Landscapes that maximize agricultural production while maintaining at least $40 \%$ of each species population on the landscape. The landscapes represent all six relationships between agricultural capacity and species capacity, as well as all three species assemblages 

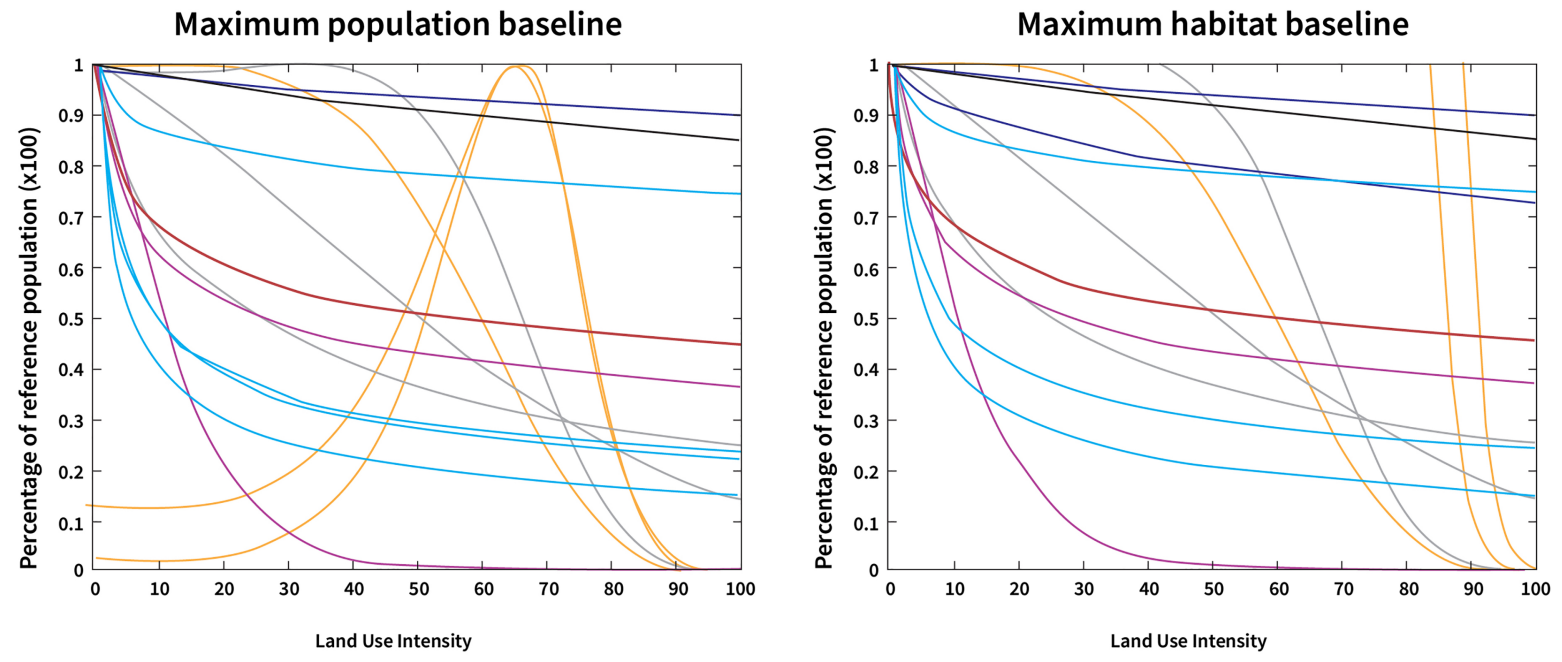

eap_2057_f1.jpg 


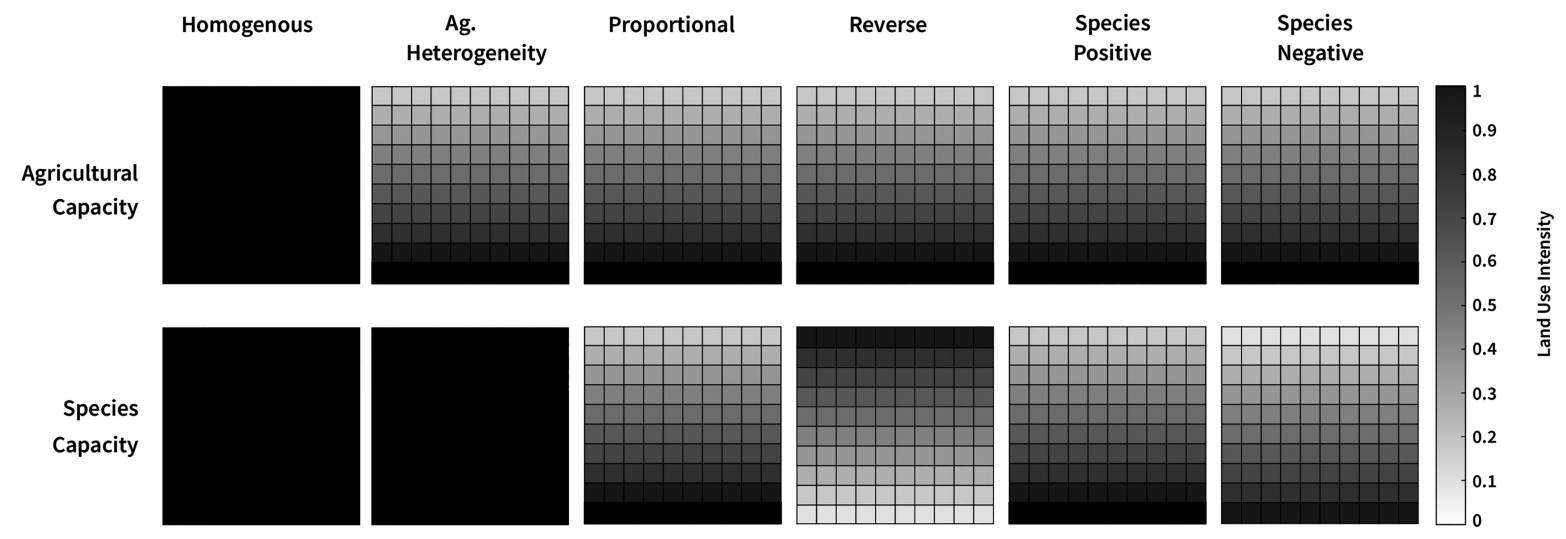

eap_2057_f2.jpg 


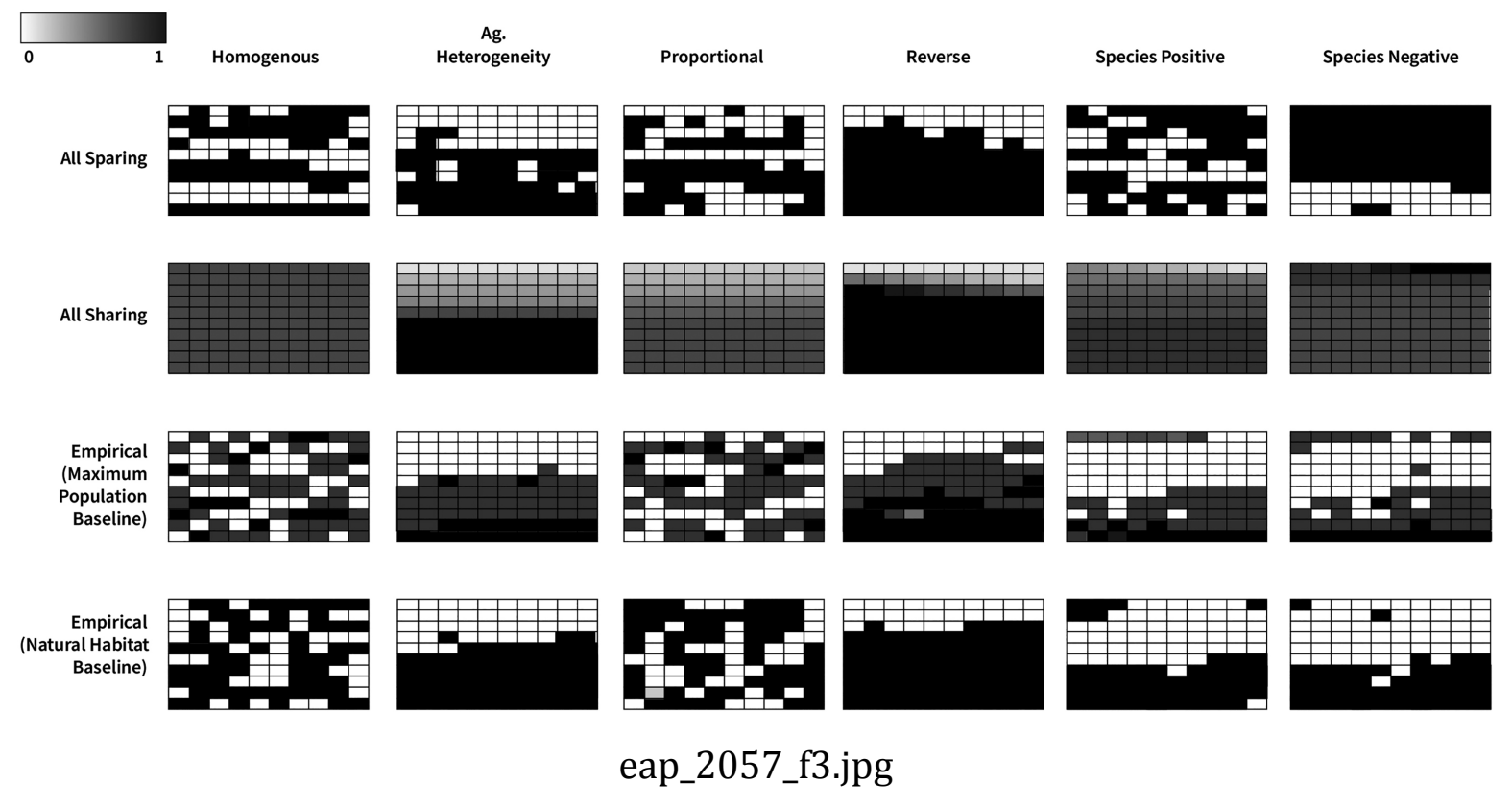

This article is protected by copyright. All rights reserved 